\title{
A Keno Trailed Vessel from the Spoonbill Site in Wood County, Texas
}

Mark Walters

Heritage Research Center, Stephen F. Austin State University

Follow this and additional works at: https://scholarworks.sfasu.edu/ita

Part of the American Material Culture Commons, Archaeological Anthropology Commons, Environmental Studies Commons, Other American Studies Commons, Other Arts and Humanities Commons, Other History of Art, Architecture, and Archaeology Commons, and the United States History Commons

Tell us how this article helped you.

This Article is brought to you for free and open access by the Center for Regional Heritage Research at SFA ScholarWorks. It has been accepted for inclusion in Index of Texas Archaeology: Open Access Gray Literature from the Lone Star State by an authorized editor of SFA ScholarWorks. For more information, please contact cdsscholarworks@sfasu.edu. 


\section{A Keno Trailed Vessel from the Spoonbill Site in Wood County, Texas}

Creative Commons License

(c) (i) (8)

This work is licensed under a Creative Commons Attribution-NonCommercial 4.0 International License 


\section{A KENO TRAILED VESSEL FROM THE SPOONBILL SITE IN WOOD COUNTY, TEXAS}

\section{Mark Walters}

A Keno Trailed vessel was discovered by J. A. Walters in 1967 at the Spoonbill Caddo site (41WD109) on the east side of Caney Creek in Wood County, Texas. The site is on a terrace 0.75 miles from Caney Creek, and 0.5 miles east of Crane Lake, a natural lake in the Caney Creek floodplain. The Spoonbill site was later investigated by Southern Methodist University archaeologists in 1979, prior to the creation of Lake Fork Reservoir (Bruseth and Perttula 1981). During construction of the reservoir, the portion of the site excavated by Mr. Walters was destroyed by new road construction.

Mr. Walters excavated a cemetery containing 15 burials (covering a $16-21 \mathrm{~m}$ diameter area), laid out in an east-west direction. The Keno Trailed vessel was from grave lot \#8. Other grave goods included Harleton Appliqued, Simms Engraved (hub-cap variety), Nash Neck Banded, and Taylor Engraved, along with a clay elbow pipe.

\section{Vessel Description}

Temper: Finely crushed shell, with leaching evident on the base of the vessel.

Finish: Polished on exterior and interior vessel surfaces. It is tan to reddish-brown in color on the exterior, and dark brown to black on the interior.

Design: Four interlocking scrolls of incised lines (Figure 1). There are nine lines in each half-scroll, except two half-scrolls with 10 incised lines. There are horizontal incised lines at the top and bottom of the design, and the lip of the vessel is notched; the notches are 4.5 mm apart.

Shape: The vessel is vase-shaped, with an orifice opening of $15.17 \mathrm{~cm}$; the basal diameter is $9.0 \mathrm{~cm}$. The lip of the vessel is thinned, and the top $5 \mathrm{~mm}$ is everted. The height of the vessel is $9.3 \mathrm{~cm}$. The vessel wall thickness is $4.8 \mathrm{~mm}$.

\section{Discussion}

Schambach and Miller (1984) state that Keno Trailed, along with Natchitoches Engraved, is a prime diagnostic of the Caddo V or historic Caddo period. From the Cedar Grove site, they illustrate a vessel similar to the one found at the Spoonbill site, and identify it as Keno Trailed var. Phillips (Schambach and Miller 1984:Figure 11-17). The var. Phillips vessels usually have notched lips, as the vessel from Spoonbill does; lip notching is uncommon in Caddo pottery, particularly in the finewares. This variety of Keno Trailed commonly occurs on sites that have a few European trade goods, and Schambach and Miller (1984) consider it a horizon marker for the first few decades of the Caddo V period (ca. 17001730). 


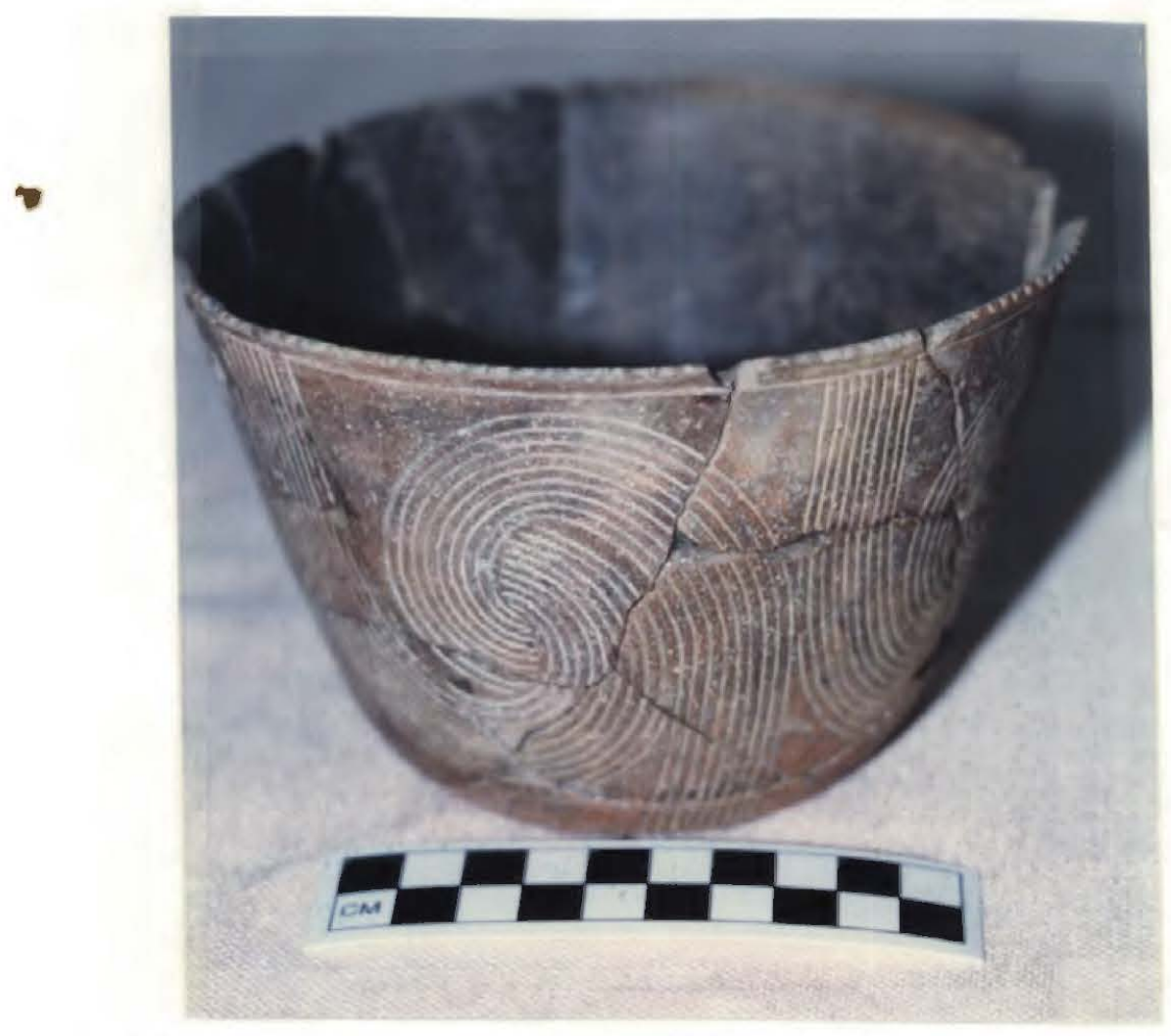

Figure 1. Keno Trailed vessel from the Spoonbill Site (41WD109).

Clarence Webb (1959:135) suggests that Keno Trailed pottery developed late in Caddoan ceramic history from the mid-Ouachita region in southwestern Arkansas, and reached its climax at the Glendora and Keno sites in the immediate pre-contact or contact period. Perino (1983:58 and Figure 14e) identifies a similar bowl from the Bob Williams site (41RR16) as "Foster Trailed-Engraved," although in other correspondence he refers to it as Keno Trailed var. Phillips.

Perttula (1992:249) states that after ca. A.D. 1600 was a period when non-local Red River ceramic wares became more common than before in East Texas. Locally manufactured ceramics no longer dominated the ceramic assemblages of East Texas Caddoan groups.

No European trade goods were found in any of the 15 burials excavated by Mr. Walters at the Spoonbill site, and thus it is presumed that this Keno Trailed vessel dates prior to sustained European contact. If this is correct, then the lack of Natchitoches Engraved and the presence of Keno Trailed var. Phillips is evidence that the Spoonbill site was occupied only to ca. 1730 (see Schambach and Miller 1984:123).

\section{References Cited}

Bruseth, J. E. and T. K. Perttula

1981 Prehistoric Settlement Patterns at Lake Fork Reservoir. Texas Antiquities Permit Series No. 2. Texas Antiquities Committee and Southern Methodist University, Austin and Dallas. 
Perino, G.

1983 Archaeological Research at the Bob Williams Site (41RR16). Museum of the Red River, Idabel, Oklahoma.

Perttula, T. K.

1992 "The Caddo Nation": Archaeological and Ethnohistoric Perspectives. University of Texas Press, Austin.

Schambach, F. F. and J. E. Miller

1984 A Description and Analysis of the Ceramics. In Cedar Grove: An Interdisciplinary Investigation of a Late Caddo Farmstead in the Red River Valley, edited by N. L. Trubowitz, pp. 109-170. Research Series No. 23. Arkansas Archeological Survey, Fayettevilie.

Webb, C. H.

1959 The Belcher Mound, a Stratified Caddoan Site in Caddo Parish, Louisiana. Memoirs No. 16. Society for American Archaeology, Salt Lake City, Utah. 